\title{
RELIGIOUS INTERPRETATION OF THE INFLUENCE OF CHRISTIANITY ON CENTRAL ASIA: MYTH AND REALITY
}

\author{
Eshkuvvatov Bobir Valikul o'g'li \\ $\mathrm{PhD}$ researcher of Tashkent State \\ Pedagogical University named after Nizami
}

Article DOI: https://doi.org/10.36713/epra4215

\begin{abstract}
It is known that Christianity began to enter the Central Asian region through Syria and Iran through the Zarafshan oasis. In this article, the issues of the spread of Christianity in the regions of our country are covered through the analysis of sources and relevant scientific literature. In our article, we also got acquainted with the results of archeological excavations conducted in the regions in order to fully substantiate the data of written sources.
\end{abstract}

\section{DISCUSSION}

Christianity is one of the most widespread world religions in the world and is widespread in Europe, America, Australia, and in several regions of Africa, the Middle East, and the Middle East as a result of active missionary activity. There are about 2 billion people in the world who practice this religion. more than one person believes. The main idea of Christianity is related to the legends about the god man - Jesus Christ (Jesus Christ). According to Christian teaching, God is one, but He appears in the Holy Trinity. This holy trinity is the God of the Father, the God of the Son-Jesus, and the God of the Holy Spirit. Jesus will return to earth on the Day of Judgment to judge the living and the dead in the future. Only those who follow his teachings and wills and endure the hardships of life like him will be rewarded in the Hereafter[National Encyclopedia of Uzbekistan. T .: "Encyclopedia". 2000. T.9.-P.250]

The doctrines, requirements of the faith, legal and moral norms, restrictions and prohibitions of Christianity are reflected in the Bible, which is their holy book. Christianity originated in the second half of the first century AD among Jews living in the eastern part of the Roman Empire.

Early Christianity was originally separated from Judaism. Some notions specific to Eastern religions are reflected in Christianity. The original social composition of Christian communities was, over time, divided into clergy (clergy) and members of the common community (mirian). The strengthening of ties between individual communities led to the formation of a church headed by a bishop. The church amassed great wealth and became a political force. The Roman emperors, who initially persecuted Christians, later became followers of Christianity. By the fourth century, Christianity had become the state religion that protected the existing social system and its order in the Roman Empire. A peculiar historical development in the western and eastern parts of the Roman Empire led to the division of the Christian Church into two: Catholicism (western part of the empire) and Orthodoxy (eastern part). Although this division of Christianity was officially recognized in 1054, the process was completed in the early thirteenth century. As a result of the reforms that took place in a number of European countries in the 16th century, a number of churches in Europe separated from Catholicism and a third major stream of Christianity, Protestantism, emerged [National Encyclopedia of Uzbekistan. T .: "Encyclopedia". 2000. T.9.-P.251]

From time immemorial, the people of Central Asia, especially Uzbekistan, have believed in different religions, and Christianity, one of the world's religions, has a special place among them. Exact information about when and by what means the first Christian communities and preachers entered the regions of Central Asia has not reached us. However, according to the Christian Church, the spread of this religion in Asian countries, India and its neighboring 
countries is associated with the name of the apostle Thomas.

According to legend, the apostle Thomas was entrusted with the divine task of preaching and preaching the true religion in the "Indian States", showing the ways of the twelve disciples of the Savior (Jesus), as the Holy Spirit determined the destiny of all mankind. This concept has been used by ancient historians who had no vague idea about Asia to represent not only India but all the countries of the East outside the Roman Empire. The Apostle Thomas was engaged in the propagation of religion not only among the Brahmins, but also among the Bactrian, Parthians, who are the ancient ancestors of the modern peoples of modern Central Asia. The closeness of this myth to the truth is confirmed by the Indian Christians, who to this day have retained the title of "Apostle Thomas Christians" for their communities [In the footsteps of the Apostle Thomas. Christianity in Central Asia. M.: "Skanrus". 2011.p.12].

The apostle Thomas traveled along the southern branch of the Great Silk Road, which connected Asia Minor with Central Asia, passed through modern Iran, and settled in the rich and glorious city of Antioch-Margiana (Marv) in the Marv oasis. As a partner in a caravan looking for lucrative deals, he reached Khorezm with the merchants, and from there the road leads to Movaraunnahr. He joined a caravan of Indian merchants in what is now Central Asian land and continued his propaganda, and was martyred in the mountains near Malipur (Il 18,20-22) when his body was pierced with spears. [In the footsteps of the Apostle Thomas. Christianity in Central Asia. M.: "Skanrus". 2011.-p.7].

According to reports, another apostle of Christ, St. Andrew, also visited Central Asia. The Lord Christ Himself, who appeared to him in Ephesus, addressed St. Andrew: "Fear not, for I am traveling with you. Even the Scythian states are waiting for you'[ Masson M.E. The origin of two Nestorian grave pebbles of Central Asia \\ ON Uz., 1978.-№10].

St. Andrew began to walk along the Northern branch of the Great Silk Road at the holy call. Five hundred years later, the Sogdian ambassador Maniax led the ambassadors of the Turkish Khanate to a treaty with Byzantium and Iran. In the northeastern Black Sea basin, the evangelist of Christ met a caravan of Sogdian merchants, and took the opportunity to enter Scythia the Great and proclaim Christ as his savior. Andrei then traveled from the Caucasus to the northern shores of the Caspian Sea, first to the deserts of Kazakhstan, and then to Khorezm. According to legend, the Apostle Andrew reached Sogdiana. On his way back through the great steppe, he preached to the Sak nomads. [N.V. Pigulevskaya. The culture of the Syrians in the
Middle Ages.- M., 1979. -P.176] . But this information has no written or archaeological basis other than the holy books of Christianity.

The Iranian state served as a gateway for the entry of Christians into Central Asia. There were Christian communities in Iran as early as the 2nd century AD. During the reign of the Sassanid ruler Yazdigar I, the independence of the Christian Church in Iran from Byzantium was recognized. During the reign of Feruz (459-484), the Nestorians were protected by the state and began to receive assistance. There were specific political reasons why Christians migrating from Byzantium were supported by the Iranian government. Because Iran was at war with Byzantium at that time. The immigrant Christian clergy were in an anti-Byzantine mood, serving the interests of Iran. But for Christians, Iran was not a peaceful place at this time, they were always doomed to live under the oppression of Zoroastrian priests. For this reason, these Christians were engaged in missionary activity [From the history of ancient cults of Central Asia. Christianity.-T., 1994.-p.10-11]

The main churches and monasteries in Central Asia were built in Ettisuv, Talas (an ancient city of the V-XVI centuries in the south of Kazakhstan, now part of Jambul), Merv, Samarkand and Khorezm oasis.

Abu Raykhan Beruni noted that the largest Christian center in the region was located in the city of Marv. The Metropolitan of Khorasan, from the city of Marv, led Christian communities and also carried out missionary work. The Metropolitan of Khorasan was given the highest religious title after successfully passing through the stages of, deacon, priest, bishop, and had a say in the Christian world all over the world. 